\title{
Erratum to: An Amalgamated Strategy for Iris Recognition Employing Neural Network and Hamming Distance
}

\author{
Madhulika Pandey and Madhulika Bhatia
}

S.C. Satapathy et al. (eds.), Information Systems

Design and Intelligent Applications, Advances in Intelligent Systems and Computing 434,

DOI 10.1007/978-81-322-2752-6_73

Erratum DOI: 10.1007/978-81-322-2752-6_76

The name of second author was inadvertently removed by Volume Editor from Chapter 73 and now he would like to include the name of second author 'Madhulika Bhatia' through this erratum.

The online version of the original chapter can be found under 10.1007/978-81-322-2752-6_73

\footnotetext{
M. Pandey $(\square)$

Pune, India

e-mail: madhulika.pandey02@yahoo.in

M. Bhatia

Amity University, Noida, Uttar Pradesh, India

e-mail: mbhadauria@amity.edu 